\title{
Attributes of Entrepreneurial Teams as Elements of a Mental Model
}

\author{
Beata Krawczyk-Brytka*
}

\begin{abstract}
An entrepreneurial team can be defined as a small group of individuals holding ownership or control positions who create or develop an entrepreneurial venture and have shared commitments towards each other. Entrepreneurial teams start numerous new ventures or affect the performance of firms due to their social capital based on some characteristic attributes. The mental models of teams refer to internal, organized representation of team tasks, relations, skills and environment. A mental model of a team is dynamic and if it is shared by team members at the beginning of the team's lifecycle, it is crucial for the team members' cooperation and influences the team's performance, satisfaction and viability. The vision of the entrepreneurial team's characteristics is an important element of its members' mental model that they start their cooperation with. The aim of this article is to define the initial mental model of an entrepreneurial team and diagnose the young Poles' image of entrepreneurial teams that can be a trigger or a barrier in developing collaborative entrepreneurship. The method used was based on a survey with open-ended questions conducted among 120 students. The presented results allow for proposing an initial mental model for cooperation in entrepreneurial teams and putting forward recommendations for preparing students for adopting a more open attitude towards team-based innovative enterprises.
\end{abstract}

Keywords: entrepreneurial teams, team effectiveness, team mental model, initial team mental model, entrepreneurship.

Submitted: 17.08.2016 | Accepted: 08.10.2016

\section{Atrybuty zespołu przedsiębiorczego jako elementy modelu mentalnego}

Zespót przedsiębiorczy może być zdefiniowany jako mata grupa osób, które sa wspótwtaścicielami firmy lub petnia w niej wysokie funkcje zwiazane z kreowaniem lub rozwojem nowego przedsięwzięcia biznesowego, wspótzależąc od siebie nawzajem. Wykorzystując swój kapitat społeczny, wynikajacy ze szczególnych cech zespotów przedsiębiorczych, tworza one wiele nowych firm i zwiększaja efektywność organizacji. Model mentalny zespotu to wewnętrzna reprezentacja obejmujaca zadania, relacje, kompetencje i otoczenie zespotu, która dynamicznie ewoluuje w procesie wspótpracy. Jeśli jest wspólna dla wszystkich osób tworzacych zespót, ma pozytywny wplyw na kooperację w zespole, jego efektywność, satysfakcję członków oraz skłonność do podejmowania wspótpracy w przysztości. Wyobrażenie dotyczace charakterystyki zespotu przedsiębiorczego jest ważnym elementem modelu mentalnego, z którym każdy z członków zespołu przystępuje do wspótpracy. Celem niniejszego artykułu jest zdefiniowanie wstępnego modelu mentalnego zespotu przedsiębiorczego oraz ocena, na ile atrybuty zespotu

\footnotetext{
Beata Krawczyk-Bryłka - PhD, Faulty of Management and Economics, Gdańsk University of Technology.

Mailing address: Faulty of Management and Economics, Gdańsk University of Technology, ul. Narutowicza 11/12, 80-233 Gdańsk; e-mail: bkrawczy@zie.pg.gda.pl.
} Ministry of Science
and Higher Education Republic of Poland
The creation of the English-language version of these publications is financed in the framework of contract No. 768/P-DUN/2016 by the Ministry of Science and Higher Education committed to activities aimed at the promotion of education. 
przedsiębiorczego w modelu mentalnym mtodych Polaków wzmacniaja lub hamuja skłonność do tworzenia nowych, zespołowych przedsięwzięć. W badaniu zastosowano metodę analizy tekstów pozyskanych $w$ odpowiedzi na otwarte pytania skierowane do grupy 120 studentów. Uzyskane wyniki pozwolity na opracowanie propozycji wstępnego modelu mentalnego zespotu przedsiębiorczego oraz na sformutowanie rekomendacji w zakresie przygotowywania studentów do podejmowania zespotowej przedsiębiorczości.

Słowa kluczowe: zespoły przedsiębiorcze, efektywność zespołu, model mentalny zespołu, wstępny model mentalny, przedsiębiorczość.

Nadesłany: 17.08.2016 | Zaakceptowany do druku: 08.10.2016

JEL: L26, M13, D83

\section{Introduction}

The myth of an entrepreneur as a lonely hero is one of the strongest ones in the context of entrepreneurial ventures and their successes. Dealing with uncertainty in changing, global and competitive environment requires combining personal and social capital of more than one person in order to overcome the barriers and achieve business success (Schjoedt and Kraus, 2009; Vyakarnam, Jacobs and Handelberg, 1999). That is the reason why entrepreneurial teams become more and more popular not only in researchers' concepts but also in entrepreneurial practice. Although entrepreneurial teams are discussed and used in two contexts, i.e. new venture creation and corporate innovativeness (Schenkel and Garrison, 2009), the first perspective will be the basic one for the current analysis. There are many benefits based on team commitment in new venture development. Teams allow for compensating individual weaknesses and gathering financial, mental and emotional experiences, skills, aptitudes and resources in order to strengthen social capital of the enterprise (Cooney, 2005). Forming an entrepreneurial team requires two or more entrepreneurial individuals who are voluntarily committed (by financial and nonfinancial motivators), proactive and responsible for the success of their new venture. In order to create an innovative venture, the team members need to be creative and open to sharing knowledge; however, there are also many other conditions that need to be fulfilled, like resource availability, team cohesiveness, team climate, participation in networks, as well as a shared vision (NaffakhiCharfeddine, 2014). The latter factor can be a part of a wider construct called $a$ team mental model, consisting of team members' internal cognitive schemas concerning team tasks and relationships (Rook, 2013). Gładys-Jakóbik (2015) refers to the concept of dominant logic and defines it as the influence of mental models on entrepreneurs' and managers' strategies as the lens they observe and understand the environment through to make their business decisions and to predict the necessary changes. Dominant logic and mental models are especially important in conditions of uncertainty because they allow for understanding and negotiating shared rules, approaches and strategies, as well as creating the common reality.

This paper presents the definition and characteristics of an entrepreneurial team and illustrates the team mental model construct in order to define the reference entrepreneurial team model that should be shared by members willing to create innovative new ventures. The main purpose of the paper is to specify the attributes making up the reference model of an entrepreneurial team and diagnose the young Poles' mental model of entrepreneurial teams that can be a trigger or a barrier in developing collaborative entrepreneurship.

\section{A Team Mental Model}

An individual mental model is an internal, cognitive representation of any external phenomena - it is based on experiences, knowledge and concepts of an individual (Rook, 2013). It influences the person's perception, judgement and behaviours. A team mental model is the cognitive representation, consisting in organized under- 
standing of task, team and environmental aspects concerning the teamwork (Santos and Passos, 2013), that changes and develops during the team collaboration. Typically, a team mental model is said to include task-related (goals, resources, tasks, procedures, scenarios, environmental constrains) and team-related (interaction, skills, behavioural tendencies of team members) knowledge (Andres, 2011; Santos and Passos, 2013). There are two most important properties of team mental models: similarity and accuracy. The first one refers to the level of the participants' mental models overlap, leading to the creation of a shared mental model. Shared team mental models mean that the knowledge about the abovementioned elements is common (Webber, Chen, Payne, Marsh and Zaccaro, 2008). A team mental model creates the team's perception of itself and the framework crucial for the team's approach and conduct. A shared team mental model influences the team processes and is crucial for team performance (Mathieu, Heffner, Goodwin, Salas and Cannon-Bowers, 2000).

The team mental models of each of the members, existing before they start collaboration, can differ to a large extent - they are influenced by perception, communication and internalization of existing differences (Davison and Blackman, 2005). In the case of an entrepreneurial team there are at least two possible situations: a trigger idea can be proposed by one person who shares it with the other members of the entrepreneurial team or a new idea for a venture can be invented by the team collectively (Cooney, 2005). In both cases the partners need to formulate a shared team mental model concerning their goals and rules of cooperation in order to start the implementation of the conceived idea. It starts the process of entrepreneurial team and enterprise formation that consists of several steps presented in Figure 1. A shared team mental model can be created upon the formation of the team, when the idea evaluation stage begins, as the interaction starts then. An initial entrepreneurial team mental model exists before this phase and refers to each participant's individual notions (Figure 1).

Davison and Balckman (2005) emphasize that sharing a team mental model "provides framework of value and belief system which acts as the basis for analysis of any new ideas, concepts, policies and cultural developments being considered by the team (...). Such shared understanding supports learning and acts as the framework for all new knowledge development". In order to stimulate innovative ideas, the shared team mental model needs to be open to new information and changes, as well as internalized by all the members. The question related to the nature of a "proper" entrepreneurial team mental model appears here. The measure of accuracy allows for assessing the degree to which the team mental model reflects the reality it refers to (Mohammed, Ferzandi and Hamilton, 2010). To assess the accuracy of members' or team's mental model, we need an expert / reference mental model which is believed to be the most correct one (Webber at al., 2008). This article concerns team mental model accuracy, which seems to be an untypical approach as researchers usually refer to similarity of shared team mental models

Figure 1. Initial and shared entrepreneurial team mental model

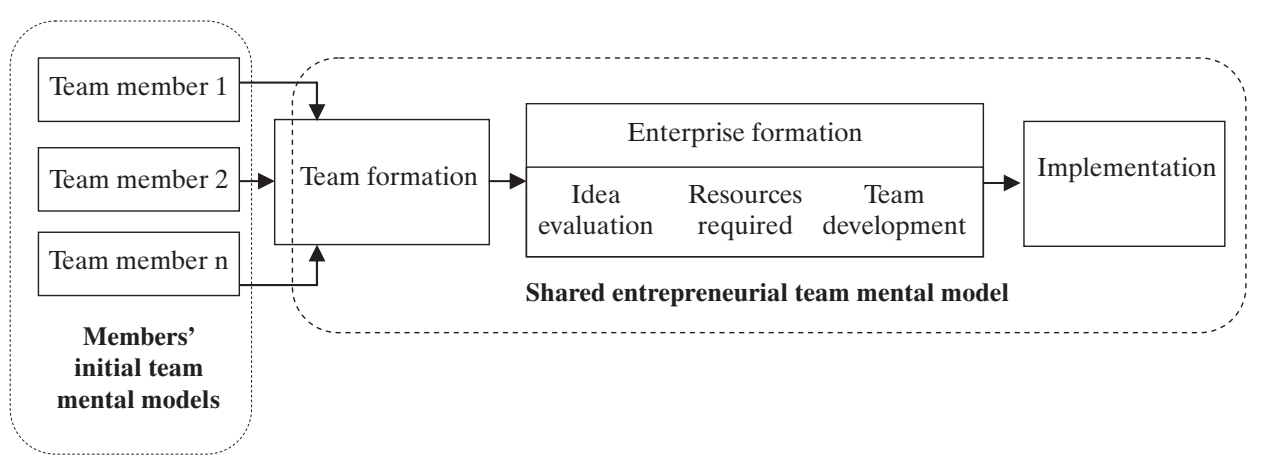

Source: own work based on Cooney (2005, p. 232).

Wydział Zarządzania UW ～DOI 10.7172/1733-9758.2016.21.1 
(Edwards, Day, Winfred and Bell, 2006). However, team mental model accuracy is a stronger predictor of team performance (Edwards, Day, Winfred and Bell, 2006). The next part of the article defines the reference entrepreneurial team mental model based on literature review. Furthermore, a research subchapter is focused on the identification of the initial entrepreneurial team mental model.

\section{Entrepreneurial Team Characteristics}

There are many reasons to use team potential in developing new ventures. The most important ones include arguments related to the assumption that teams are better than individuals at responding to environmental complexity and changes, as well as superior at responding to challenges, troubles and crises. It is said that teamwork is one of the most important conditions of enterprise growth and the synergic effects stimulate business performance. While working in teams, people feel the support and fulfil their affiliation needs, which increases their satisfaction and reduces their stress level (Tihula, Huovinen and Fink, 2009). To be considered entrepreneurial, however, a team needs to seek opportunities and be motivated to "bring into existence future goods and services" (Shepherd and Kruger, 2002, p. 170). The entrepreneurial orientation of a team means also innovativeness, openness to risk, proactivity, ability to compete and goal orientation (Schenkel and Garrison, 2009). The definition of an entrepreneurial team proposed by Schjoedt and Karaus (2009) emphasizes the most important traits determining these abilities: "An entrepreneurial team consists of two or more persons who have interest, both financial and otherwise, in and commitment to a venture's future and success; whose work is interdependent in the pursuit of common goals and venture success; who are accountable to the entrepreneurial team and for the venture; who are considered to be at the executive level with executive responsibility in the early phases of the venture, including founding and pre-start up; and who are seen as a social entity by themselves and by others" (Schjoedt and Karaus, 2009). Naffakhi-Charfeddine (2014) completes this approach and adds that an entrepreneurial team can be focused on any entrepreneurial project based on strategic vision and needs to be active during its evolution without any supervisors' pressure. The leadership in an entrepreneurial team is shared and supports the collaboration, coordination and innovation processes, which positively influences the performance of the new company.

The venture dynamic requires the members' flexibility and their will to modify their roles in the entrepreneurial team or even ability to leave it or accept participation of new members, which is essential for the venture performance (Zolin, Kuckertz and Kauonen, 2011). The composition of an entrepreneurial team has decisive impact on its relational capital. From one perspective, it seems reasonable to form an entrepreneurial team with the persons we have strong ties with (Aldrich and Kim, 2007). It helps to avoid the risk connected with the involvement of strangers and allows for capitalizing on friendliness inside the team. Team cohesion, respect and trust are necessary conditions for knowledge sharing and innovative decisions (Schenkel and Garrison, 2009). From another point of view, searching for networks based on weaker ties and indirect relations provides a chance to recruit the best experts and gain accurate information, knowledge and expertise (Aldrich and Kim, 2007).

Another entrepreneurial team's attribute is collective efficacy (Shepherd and Kruger, 2002). It is (like self-efficacy in the individual entrepreneurship approach) correlated with new venture creation and means the team's belief in its effectiveness and ability to achieve the goals at the planned level. It is not just the sum of team members' self-efficacy but it is built during the team's collaboration process. It is based on the knowledge of context, task, relationship, other members and prior performance and results in better team performance in the area it refers to. It is subjective and shared by team members, as well as inspires the team's entrepreneurial intention.

The collective efficacy also seems to be correlated with the team members' belief that the necessary resources needed to analyse and answer market needs are available (Schenkel and Garrison, 2009).

The next attribute of an entrepreneurial team transferred from the characteristics 
of an individual entrepreneur is the internal locus of control. This factor is a valuable predictor of personal entrepreneurial success but also allows for expecting the entrepreneurial team to be effective and use resources in an optimal way (Khan, Breitencker and Schwarz, 2014). The positive impact of internal locus of control in the team context is reinforced by affective trust between team members.

Heterogeneity, which refers to surface (demographics, experience) and deep (traits like personality, values, attitudes, cognitive styles) levels, is said to be an important attribute of effective entrepreneurial teams. However, heterogeneity needs to be balanced with homogeneity to let the team cooperate effectively and maintain the cognitive conflict that allows for taking creative decisions (Schjoedt and Kraus, 2009; Naffakhi-Charfeddine, 2014). Heterogeneity refers also to team members' knowledge - that is why knowledge sharing and transforming is one of the most important team processes in new venture creation and development. Homogeneity can be beneficial while speaking about members' psychological traits, e.g. locus of control: a high level of the internalization of the locus of control makes entrepreneurial teams more effective (Khan, Breitencker and Schwarz, 2014). Homogeneity should also concern the team mental model integrating all the members' knowledge and notions about the team's mission, goals and tasks, as well as team processes. It provides the team's cognitive capital necessary for the exploration of strategic vision.

The findings mentioned above allow for framing the main attributes of an entrepreneurial team. They create a complex model which can be treated as the reference one, as the prototype model of an entrepreneurial team. It is presented in Figure 2. All these attributes influence the entrepreneurial team's processes and determine the way the team members make decisions, create the team strategy and perform together. The attributes can be grouped into two categories: the ones concerning the task and the ones concerning the team relationships. This division is also presented in Figure 2.

To create a shared mental model of an entrepreneurial team, all the participants should agree upon most elements of the reference model and use it as the team capital. The basic condition influencing the possibility of shared mental model creation is related to the initial team mental models of the members. The research presented in the next section concerns business students' entrepreneurial team mental model. Its main aim was to assess its compatibility with the reference entrepreneurial team mental model presented below.

\section{Attributes of an Entrepreneurial Team - Research Results}

In order to identify the initial entrepreneurial team mental model of 120 business students from the Gdańsk University of Technology, they were tested with a questionnaire composed of two open-ended questions: What is an entrepreneurial team? and: What are the characteristics of an entrepreneurial team? The group was chosen because more than $60 \%$ of its members declare that they plan to create a new venture in the future. In order to analyse the participants' team mental models, a textual analysis focused on content was used (Mohammed, Ferzandi and Hamilton, 2010; Szczepaniak, 2012). Their answers were categorized by key words related to the entrepreneurial team attributes shown in Figure 2. For example, if the answer included key words like "innovation", "creativity" or "unconventional", it was classified as belonging to the "innovativeness" category. Every answer could be classified into multiple categories if it included key words that suited more than one attribute. The frequency of words related to each of the entrepreneurial team's attributes is presented in Figure 3.

The answers referring to entrepreneurial tasks (shown in the upper part of the graph) were most frequent, especially in the case of the "goal orientation" attribute. For about $30 \%$ of students, an entrepreneurial team is a team which collaborates to achieve a goal - they usually do not define it more precisely. Some answers in this category were developed with additional elements: "An entrepreneurial team is a group of people who learn all the time and achieve short- and long-term goals thanks to collaboration", "People who play together to achieve a creative goal by using all the opportunities that appear" or "The team members are interdependent and 
Figure 2. Reference model of entrepreneurial team

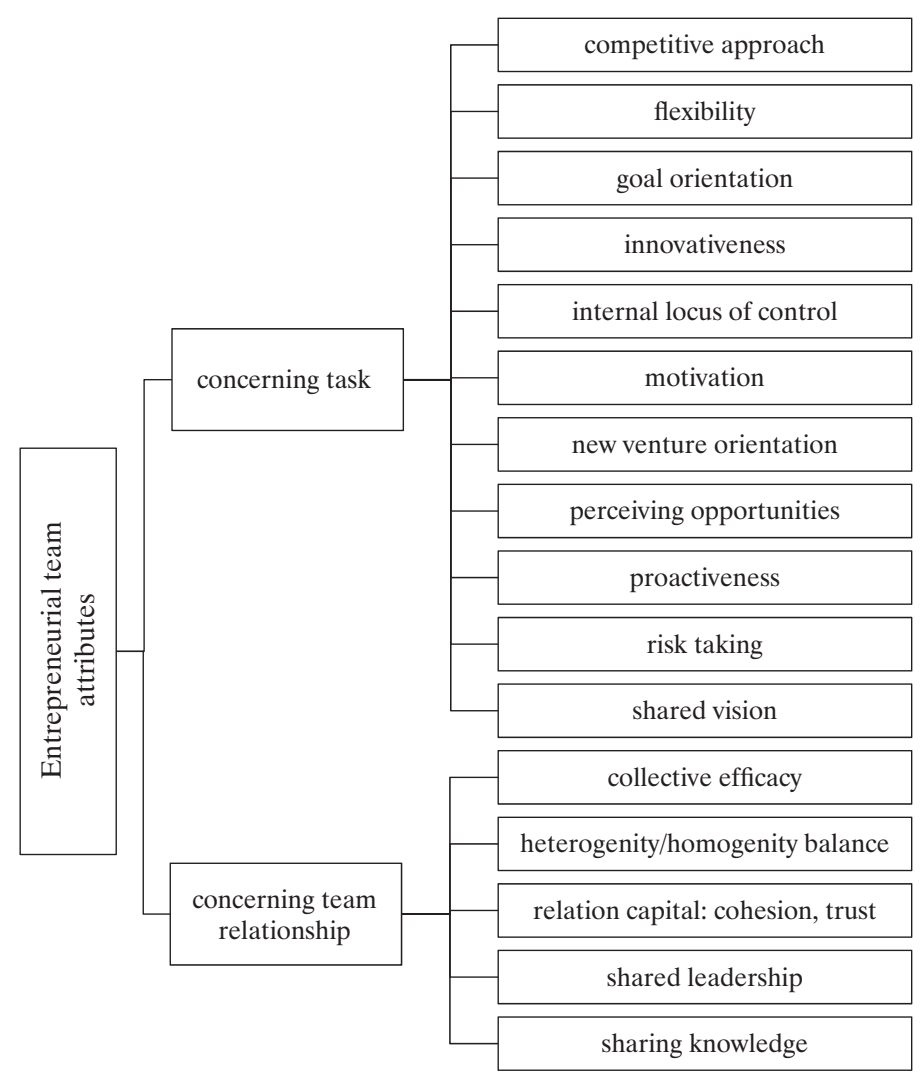

Source: own work.

interconnected thanks to a common goalthey analyse data and propose resolutions, while taking under consideration all the opinions".

There were no answers referring to the "shared vision" attribute directly; however, all the answers where the common goal or the same goal was pointed to were classified as belonging to this category. Innovativeness was the second most frequent attribute in respondents' entrepreneurial team mental model. There were 25 answers like "A creative team which does not think in a conventional way in order to be able to create an enterprise in an effective way", "A group of inventive people who implement various new initiatives", "An entrepreneurial team generates creative resolutions, is brave and innovative, as well as creates the new venture together". An interesting result was that the students mentioned the new venture context quite seldom. It was present in only 8 answers. Another four participants stressed that entrepreneurial teams operate inside a company, e.g.: "A team collaborating to achieve a goal in a company, for example a project". The least popular attribute in task entrepreneurial team mental model was the competitive approach. Only one student mentioned "A group of people characterized by approaches like exploiting opportunities and winning at the market", which can be interpreted as the competitive approach. Another answer was: "The entrepreneurial team is aware of the market conditions..." but it was given in the context of perceiving opportunities.

The internal locus of control, which means the belief that the effect depends on the team, was not expressed at all; however, it should be noted here that there were many answers stressing the entrepreneurial team's effectiveness. They can be an indicator of team's locus of control or 
Figure 3. Students' entrepreneurial team mental model

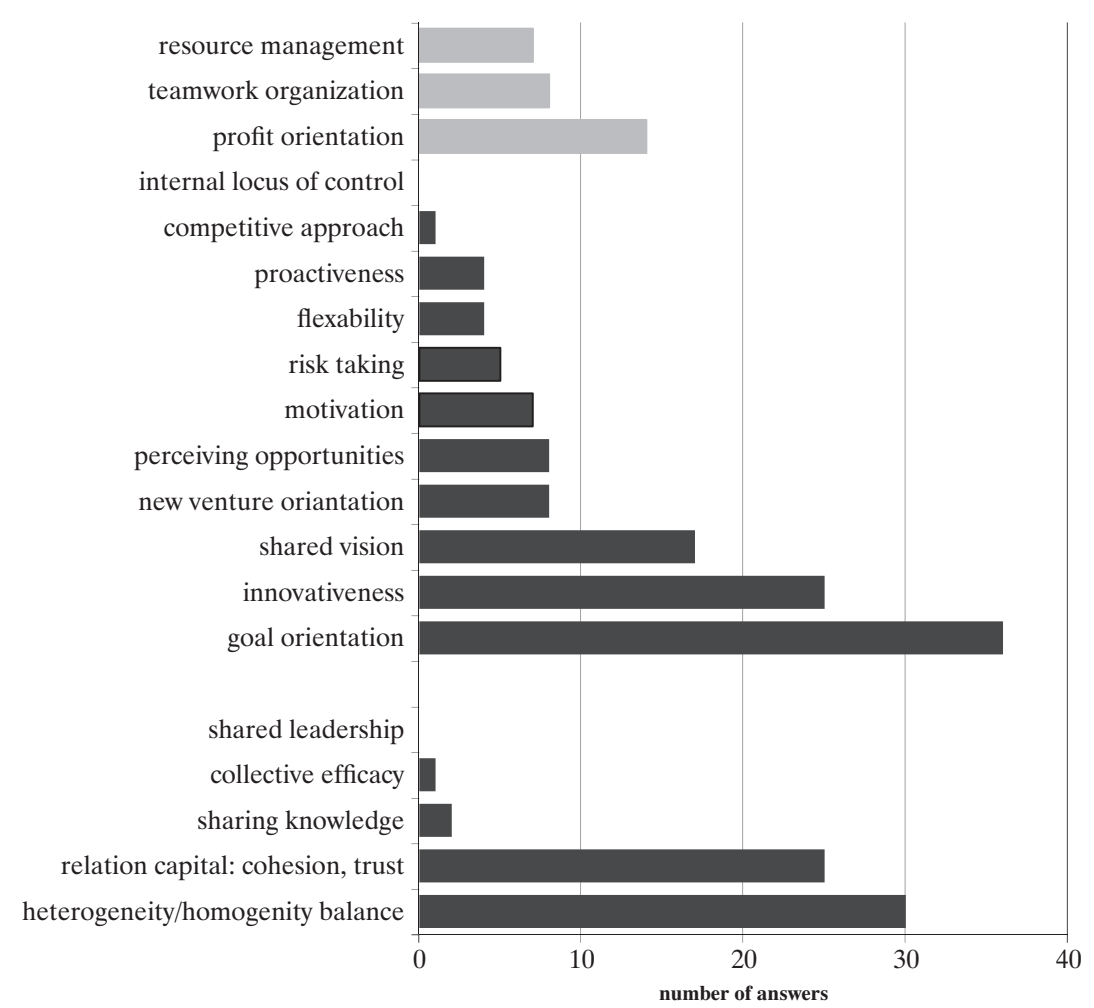

Source: own preparation.

efficacy but it needs to be investigated in another study.

The lower part of Figure 3 presents the relationships between the elements of entrepreneurial team mental model. Heterogeneity/homogeneity balance was found in 30 answers. They were usually related to the need of complementary team members' competencies: "The group of people who complement each other in reaching entrepreneurial goals", "People who have one goal and different expert knowledge" or "An entrepreneurial team is synergic but it is composed of people with different points of view and different ways of problem solving. All the members should also be very creative as well as have high level of self-fulfilment need and communication skills". Homogeneity refers to psychological traits, system of values and rules: "People who are independent, creative and intelligent and collaborate according to the same game rules", "Ambitious and entrepreneurial people with different experiences who work hard and solidly to achieve suc- cess". The most popular trait mentioned as the common one for entrepreneurial team members was entrepreneurship. Unfortunately, most students have not explained it in detail.

Good relationships based on trust and two-way open communication were the second most often mentioned attribute. The students answers' were: “A cohesive group of people who cope together in a crisis situation, collaborate together to solve all the problems and understand each other", "A highly-integrated team with strong team spirit and sense of responsibility for successes and failures", "People who trust and help each other to achieve profit", "An entrepreneurial team is a well-organized group of people working towards the same goal. It is also the place where you can reveal your ideas while being sure that your peers will support you. If they criticize you, it will be constructive, merit-based feedback. You can propose the most innovative resolutions there because you can be sure that the other members are 
open to them - they are success-oriented, do not give up when difficulties appear and learn to react flexibly to challenges and changes". An interesting fact is that the answers concerning team relationships usually refer to challenges or barriers that need to be overcome.

There were also three additional attributes present in the respondents' entrepreneurial team mental models: profit orientation, resource management and teamwork organization. All of them refer to the task entrepreneurial team mental model and include answers like: "All the team members are focused on achieving profit", "A group of people who work successfully together to achieve profit for the company" or "An ambitious team which pursues the goal and uses all the available resources". One of respondents understood the profit not just as financial success: "An entrepreneurial team is a group of members with similar personalities, who take creative decisions to achieve profit and work for society". The teamwork organization refers to the temporal team mental model (time, task sequences, speed) (Santos, Passos and Uitdewilligen, 2015) and the exemplary answers were: "A rational, conscientious and well-organized team collaborating to achieve business goals", "A team which collaborates is able to organize its work and act effectively" or "A team which is focused on entrepreneurial tasks is able to plan and organize the workflow". All these answers stress that an entrepreneurial team is a self-organizing, independent construct; however, there were no answers concerning shared leadership, which includes collaborative decision making and empowerment.

There were also 15 answers that could be not classified into any attribute category due to being essentially meaningless: " $A n$ entrepreneurial team is a group characterized by entrepreneurial traits" or "A team working on an entrepreneurial task".

\section{Conclusions}

This article presents a reference entrepreneurial team mental model proposal based on literature review. The initial entrepreneurial team mental model is also interpreted as the individuals' representation of an entrepreneurial team working on new venture creation. However, the results reached are the source of many questions rather than answers.

The surprising result was that the majority of respondents understand the entrepreneurial team as close to a typical (project) team: they think that it focuses on achieving goals and trust-based collaboration, which seems to be not enough to create a new venture. It can be related to the fact that Polish students usually do not associate setting up one's own company with team activity (Krawczyk-Bryłka, 2016).

Another conclusion that arises from the research is that initial entrepreneurial team mental models can be different from each other and can mirror the reference model at different levels. This emphasizes the importance of diagnosing and discussing the partners' models before starting the new venture creation in order to make mutual expectations and future collaboration rules and goals clear. From another point of view, it can be helpful to assess such models if the initial entrepreneurial team mental model can cause the "singleminded view", which is risky for team creativity, effective resource exploration and efficient problem solving (Tzeng, 2006).

It is difficult to assess the accuracy of the participants' entrepreneurial team mental model. The reason is that the reference model seems not to be analysed and structured enough. All the attributes generated in scientific research were tested separately. It seems to be necessary to elaborate a complex entrepreneurial team mental model. Opinions of efficient entrepreneurial teams should be taken under consideration while preparing it to make it as real as possible. The conducted research suggests that the reference entrepreneurial team mental model should be supplemented with additional attributes like profit orientation, resource management or teamwork organization. One of the students defined the entrepreneurial team as "Fair collaboration which creates the added value for the team and its environment". This opinion fits in the trend of RBC (Responsible Business Conduct) - the approach promoted by OECD (2014), which is insufficiently explored in the new team venture context and could possibly supplement the reference model, too.

It would also be interesting to evaluate the importance of each of the attributes according to the circumstances in which 
the entrepreneurial team collaborates. For example, the respondents seem to appreciate the other team members' support in crisis situations. Are the other elements of the reference team mental model more important when the company is in the prosperity phase?

Another challenge concerning team mental models is caused by the fact that nowadays more and more teams work in virtual environments. It refers also to entrepreneurial virtual teams, in which it is much harder to recognize teammates' intentions, their approaches towards tasks and their way of perceiving aims and relationship. Face-to-face teams are usually able to develop an accurate shared mental model of task requirements and task status much earlier than virtual ones (Anders, 2011). This dependence stresses the importance of taking into account the initial mental model if the team members are expected to share the approach and collaborate in a more effective or innovative way. It makes clear goal communication and rules introduction in virtual teams necessary to build the shared mental models already from the beginning of the team processes.

All the reasons given above prove that the subject of an entrepreneurial team mental model needs to be explored in future scientific investigations.

\section{References}

Aldrich, H.E. and Kim, P.H. (2007). Small Words, Infinite Possibilities? How social Networks Affect Entrepreneurial Team Formation and Search. Strategic Entrepreneurship Journal, 10, 147-165, DOI: 10.1002/sej.8.

Anders, H.P. (2013). Team cognition using collaborative technology: a behavioral analysis. Journal of Managerial Psychology, 28(1), 38-54, DOI: $10.1108 / 02683941311298850$

Cooney, T. (2005). What is an Entrepreneurial Team? International Small Business Journal, 23(3), 226-235, DOI: $10.1177 / 0266242605052131$.

Davison, G. and Blackman, D. (2005). The role of mental models in innovative teams. European Journal of Innovation Management, 8(4), 409-423, DOI: 10.1108/14601060510627795.

Edwards, B.D., Day, E.A., Winfred, A.J. and Bell, S.T. (2006). Relationship Among Team Ability Composition, Tam Mental Models, and Team Performance. Journal of Applied Psychology, 91(3), 727-736. DOI: 10.1037/0021-9010.91.3.727.
Khan, M.S., Breitencker, R.J. and Schwarz, E.J. (2014). Entrepreneurial team locus of control: diversity and trust. Management Decision, 52(6), 1057-1081. DOI: http://dx.doi.org/10.1108/MD-062013-0349.

Krawczyk-Bryłka, B. (2016). Indywidualizm versus zespołowość - $\mathrm{w}$ jakich kategoriach myślimy o przedsiębiorczości. Accepted to print in: Edukacja Ekonomistów i Menedżerów. Quarterly of Institute of Human Capital.

Gładys-Jakóbik, J. (2015). Zmiana modeli mentalnych, jako reakcja na niepewność (nie tylko) organizacyjną. Marketing i Rynek, 5, 1112-1136.

Mathieu, J.E., Heffner, T.S., Goodwin, G.F., Salas, E. and Cannon-Bowers, J.A. (2000). The Influence of Shared Mental Models od Tam Process and Performance. Journal of Applied Psychology, 85(2), 273-283. DOI: 10.1037/0021-9010.85.2.273.

Mohammed, S., Ferzandi, L. and Hamilton, K. (2010). Metaphor No More: A 15-Year Review of the Team Mental Model Construct. Journal of Management, 36(4), 876-910, DOI: 10.1177/0149206309356804.

Naffakhi-Charfeddine, H. (2014). Knowledge Creation In Entrepreneurial Teams. In: R. Sternberg and G. Krauss, Handbook of Research on Entrepreneurship and Creativity (pp. 122-144). UK: Edward Elgar Publishing. Inc.

OECD (2014). OECD Guidelines for Multinational Enterprises. Retrieved from: https://mneguidelines.oecd.org/MNEguidelines_RBCmatters.pdf (07.07.2016).

Rook, L. (2013). Mental models: a robust definition. The Learning Organization, 20(1), 38-47, DOI: 10.1108/09696471211288519.

Santos, C.M. and Passos, A.M. (2013). Team mental models, relationship conflict and effectiveness over time. Team Performance Management, 19(7/8), 363-385. DOI: http://dx.doi.org/10.1108/TPM-012013-0003.

Santos, C.M., Passos, A.M. and Uitdewilligen, S. (2015). When shared cognition leads to close mind: Temporal mental models, team learning, adaptation and performance. European Management Journal, XXX, 1-11, DOI: 10.1016/j.emj.2015. 11.2006.

Schenkel, M.T. and Garrison, G. (2009). Exploring the roles of social capital and team-efficacy in virtual entrepreneurial team performance. Management Research News, 32(6), 525-538, DOI: 10.1108/-1409170910962966.

Schjoedt, L. and Kraus, S. (2009). Entrepreneurial teams: definition and performance factors. Management Research News, 32(6), 513-524. DOI: 10.1108/01409170910962957.

Shepherd, D.A. and Krueger, N.F. (2002). An Intentions-Based Model of Entrepreneurial Teams' 
Social Cognition. Entrepreneurship Theory and Practice, winter, 167-185.

Szczepaniak, K. (2012). Zastosowanie analizy treści w badaniach artykułów prasowych - refleksje metodologiczne. Acta Universitatis Lodziensis, Folia Socjologica, 42, 83-112.

Tihula, S., Huovinen, J. and Fink, M. (2009). Entrepreneurial teams vs managerial teams. Reasons for team formatting in small firms. Management Research News, 32(6), 555-566, DOI: 10.1108/01409170910962984.

Tzeng, J.Y. (2006). Developing and Sharing Team Mental Models in Profession-driven and Value laden Organization. Performance Improvement Quarterly, 19(2), 155-172.
Zolin, R., Kuckerts, A. and Kautonen, T. (2011). Human resource flexibility and strong ties in entrepreneurial teams. Journal of Business Research, 64, 1097-1103, DOI: 10.1016/j. jbusters.2010.11.026.

Vyakarnam, S., Jacobs, R. and Handelberg, J. (1999). Exploring the formation of entrepreneurial teams: The key to rapid growth business? Journal of Small Business and Enterprise Development, 6(2), 153-165.

Webber, S.S., Chen, G., Payne, S.C., Marsh, S.M and Zaccaro, S.J. (2008). Enhancing Team Mental Model Measurement With Performance Appraisal Practices. Organizational Research Methods, 3(4), 307-322. 